\title{
ANTIOXIDANT ACTIVITY OF WATER APPLE (SYZYGIUM AQUEUM) FRUIT AND FRAGRANT MANGO (MANGIFERA ODORATA) FRUIT
}

\author{
NYI MEKAR SAPTARINI ${ }^{1 *}$, IRMA ERIKA HERAWATI ${ }^{2}$ \\ ${ }^{1}$ Department of Pharmaceutical Analysis and Medicinal Chemistry, Faculty of Pharmacy, Universitas Padjadjaran, Indonesia. ${ }^{2}$ Department \\ of Pharmacy, FMIPA, University of Al Ghifari, Indonesia. Email: nyi.mekar@unpad.ac.id
}

Received: 16 October 2016, Revised and Accepted: 24 January 2017

\section{ABSTRACT}

Objective: The aim of this study was to compare the antioxidant activity of fruit of water apple and fragrant mango against 1,1-diphenyl-2picrylhydrazyl as a free radical.

Methods: This study was conducted by visible spectrophotometry.

Results: The water apple and fragrant mango contain reducing compounds including vitamin $\mathrm{C}$. The vitamin $\mathrm{C}$ content of water apple and fragrant mango fruit was $0.087 \%(\mathrm{w} / \mathrm{w})$ and $0.050 \%(\mathrm{w} / \mathrm{w})$, respectively. The inhibitory concentration $50 \%$ value of fresh fruit of water apple and fragrant mango was $4.857 \mu \mathrm{g} / \mathrm{ml}$ and $4.379 \mu \mathrm{g} / \mathrm{ml}$, respectively.

Conclusion: Antioxidant activity of water apple fruit was higher than fragrant mango fruit.

Keywords: 1,1-diphenyl-2-picrylhydrazyl, Free radical, Visible spectrophotometry, Vitamin C.

(C) 2017 The Authors. Published by Innovare Academic Sciences Pvt Ltd. This is an open access article under the CC BY license (http://creativecommons. org/licenses/by/4. 0/) DOI: http://dx.doi.org/10.22159/ajpcr.2017.v10s2.19487

\section{INTRODUCTION}

Free radicals are responsible for the damage of lipids, proteins, and nucleic acid in cells [1] which lead to cardiovascular diseases, cancers, and other age-related degenerative diseases [2]. Fruits and vegetables can reduce the risk of stroke and cancer because of the antioxidant contained in the plant parts. Different fruits have different capacities due to different dietary antioxidants such as vitamin C, flavonoids, and other phenolic compounds [3].

Fruit of water apple (Syzygium aqueum (Burm.f.) Alston) and fragrant mango (Mangifera odorata Griffith) contains vitamin C. All physiological and biochemical actions of vitamin $\mathrm{C}$ are due to its action as an electron donor from a double bond. Vitamin $\mathrm{C}$ is an antioxidant, because of donating its electrons, which prevents other compounds from being oxidized. When vitamin $\mathrm{C}$ donates one electron, they are formed a free radical, semi-dehydroascorbic acid, or ascorbyl radical, which relatively stable $\left(10^{-5}\right.$ seconds of half-life) and fairly unreactive [4]. The aim of this study was to compare the antioxidant activity of fruit of water apple and fragrant mango against 1,1-diphenyl-2-picrylhydrazyl (DPPH) as a free radical.

\section{MATERIALS AND METHODS}

Materials

Fruit of water apple and fragrant mango was collected from Subang subdistrict, Indonesia, in July 2016. Fruits were identified by Laboratory of Plants Taxonomy, Department of Biology, Universitas Padjadjaran, Indonesia, with No. 450/HB/08/2016. All chemical reagents are analytical grade (Merck) including DPPH (Sigma-Aldrich).

\section{Methods}

\section{Extraction}

A total of $10 \mathrm{~g}$ of fruit and $15 \mathrm{ml}$ of citrate buffer $\mathrm{pH} 4.2$ were mashed and filtered into a $25 \mathrm{ml}$ volumetric flask. The extract was centrifuged at $5000 \mathrm{rpm}$ for 15 minutes to obtain supernatant. Citrate buffer $\mathrm{pH} 4.2$ was added to the supernatant $(1.0,1.5,2.0,2.5$, and $3 \mathrm{ml})$ in a $10 \mathrm{ml}$ volumetric flask for antioxidant activity determination.
The moisture content determination

A total of $5 \mathrm{~g}$ of fruit was dried on $105^{\circ} \mathrm{C}$ at atmospheric pressure for $5 \mathrm{hrs}$, then weighed. Drying and weighing continued, every $1 \mathrm{hr}$, until a constant weight [5].

Qualitative analysis of reducing compounds

A total of $0.2 \mathrm{ml}$ of $1 \%$ iodine solution was added to $2 \mathrm{ml}$ of supernatant. The discoloration of the brown color was indicated the positive reaction.

\section{Quantitative analysis of vitamin C}

A total of $2 \mathrm{ml}$ of $25 \mu \mathrm{g} / \mathrm{ml}$ methylene blue and $2 \mathrm{ml}$ of distilled water incubated for 10 minutes. The absorbance was measured at $400-900 \mathrm{~nm}$ with spectrophotometer against distilled water as blank. A total of $2 \mathrm{ml}$ of $25 \mu \mathrm{g} / \mathrm{ml}$ methylene blue was added to $2 \mathrm{ml}$ of standard vitamin $\mathrm{C}(2,4,6$, 8 , and $10 \mu \mathrm{g} / \mathrm{ml}$ ) or supernatant in $10 \mathrm{ml}$ volumetric flask, accomplished with citrate buffer $\mathrm{pH} 4.2$. The mixture was incubated for 10 minutes, then the absorbance was measured at maximum wavelength [6].

\section{Antioxidant activity determination}

The modified method of Molyneux (2004) was conducted [7]. A total of $1.5 \mathrm{ml}$ of $40 \mu \mathrm{g} / \mathrm{ml}$ DPPH was added to various concentrations of $1.5 \mathrm{ml}$ of vitamin $\mathrm{C}$ or supernatant. The mixtures were incubated in a dark chamber for 30 minutes, then absorbance was measured at $517 \mathrm{~nm}$ using spectrophotometer (Ray Leigh). The blank was $96 \%$ ethanol. Percentage of antioxidant activity was calculated using this formula:

$$
\% \text { of DPPH inhibition }=\frac{(\mathrm{Ab}-\mathrm{Aa})}{(\mathrm{Ab})} \times 100
$$

$\mathrm{Aa}$ and $\mathrm{Ab}$ are the absorbance values of the sample and the blank, respectively. A percent inhibition versus concentration was plotted, and the concentration of sample required for $50 \%$ inhibition was determined and expressed as inhibitory concentration $50 \%\left(\mathrm{IC}_{50}\right)$ value.

Statistical analysis

The results were presented as the mean \pm standard error of the mean. Data comparisons between groups were done by one-way ANOVA 
followed by t-test. Values were considered statistically significant at $\mathrm{p}<0.05$.

\section{RESULTS}

A total of $10.127 \pm 0.005 \mathrm{~g}$ of water apple fruit was produced the turbid pink extract, whereas $10.036 \pm 0.232 \mathrm{~g}$ of fragrant mango was produced the turbid yellow extract. The turbid extract was centrifuged to obtain a clear supernatant, pink for water apple and yellow for fragrant mango. The moisture content for water apple and fragrant mango was $92.847 \pm 0.059 \%$ and $84.927 \pm 0.099 \%$, respectively. Water apple and fragrant mango supernatant were given the positive results.

There were statistically significant differences between groups on vitamin $\mathrm{C}$ content $\left(\mathrm{p}=3.65 \times 10^{-4}\right)$ and $\mathrm{IC}_{50}$ value $\left(\mathrm{p}=2.19 \times 10^{-6}\right)$.

\section{DISCUSSION}

Citrate buffer $\mathrm{pH} 4.2$ was used to extract the reducing compounds, especially vitamin $\mathrm{C}$, which is present in the fruit. Citrate buffer $\mathrm{pH} 4.2$ was selected because of vitamin $\mathrm{C}$ is stable at acidic pH. Aqueous solutions are most stable at $\mathrm{pH}$ 5-6 and very unstable at alkaline $\mathrm{pH}$ [8]. The water apple and fragrant mango extracts were turbid, so centrifugation was conducted to separate the supernatant which contains the secondary metabolites from the residues. The moisture content for both fruits was high (more than $80 \%$ ), which shown the content of water and volatile compounds in fruits. These values were determined to calculate the vitamin $\mathrm{C}$ content in dried plant materials because the used samples were fresh fruits.

Qualitative analysis of reducing compounds, including vitamin C in the supernatant, was showed the positive results. There was the oxidation-reduction reaction, the vitamin $\mathrm{C}$ is oxidized by the iodine into dehydroascorbic acid, and the iodine is reduced [9]. These results indicate the presence of a reducing compound in the supernatant which can react with DPPH as free radical oxidants.

Table 1: Vitamin C content in fruit

\begin{tabular}{llll}
\hline Sample & Absorbance & $\begin{array}{l}\text { Vitamin C } \\
\text { content }(\boldsymbol{\mu g} / \mathbf{m l})\end{array}$ & $\begin{array}{l}\text { Vitamin C } \\
\text { content } \\
(\% \mathbf{w} / \mathbf{w})\end{array}$ \\
\hline Water apple & $0.886 \pm 0.001$ & $4.047 \pm 0.115$ & $0.087 \pm 0.002$ \\
Fragrant mango & $0.894 \pm 0.001$ & $2.313 \pm 0.115$ & $0.050 \pm 0.002$ \\
\hline \multicolumn{2}{l}{ Values are mean+SD (n=3),SD: Standard deviation }
\end{tabular}

Quantitative analysis of vitamin C was based on oxidation-reduction reactions which observed from discoloration of methylene blue to leucomethylene blue, from blue to colorless [6]. The methylene blue solution was provided the maximum wavelength at $664.4 \mathrm{~nm}$. This wavelength was consistent with the literature [6]. The instrument response was proportional to the vitamin $\mathrm{C}$ content, due to the correlation coefficient was 0.9993 (Fig. 1) which meets the criteria by ICH [10].

The vitamin C content in both fruits was small (Table 1) because of the used sample was fresh fruit with high moisture content. If converted to a dried plant material, the vitamin $\mathrm{C}$ content for water apple and fragrant mango was $1.216 \pm 0.001 \%$ and $0.332 \pm 0.001 \%(\mathrm{w} / \mathrm{w})$, respectively. High vitamin C content in water apple due to the time harvest was the harvest season for water apple in July to August in Indonesia [11]. Low vitamin C content in fragrant mango due to the time harvest was not the harvest season, i.e., from September to December in Indonesia [12]. This study was conducted in July, so we suggested that the secondary metabolites content in fragrant mango were not maximally produced.

The chemical composition of horticultural crops was influenced by climatic conditions including light and average temperature [13]. The intensity and amount of light during the growing season influence the vitamin C content because of vitamin C was synthesized from sugars through photosynthesis. The outside fruit which exposed to maximum sunlight contains a higher amount of vitamin C than inside and shaded fruit on the same plant [14]. Climatic conditions and cultural practices also influence the preharvest $[8,15]$. The plant maturity when harvested, harvesting method, postharvest handling conditions [16],

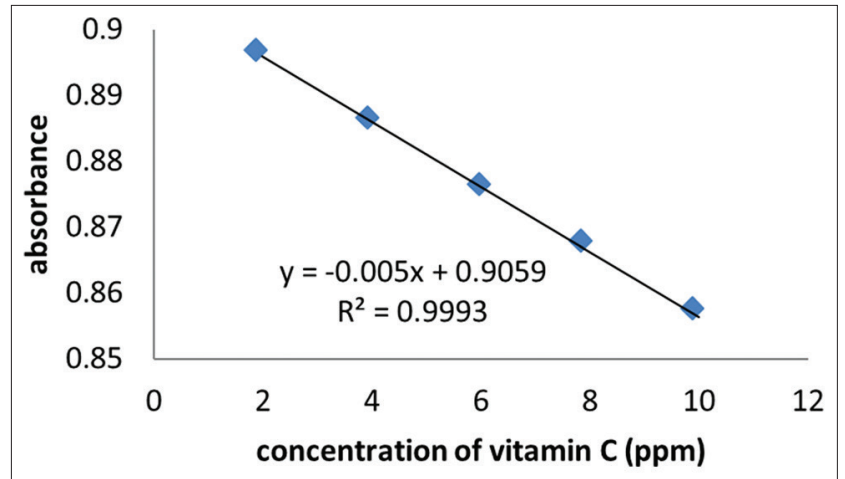

Fig. 1: Calibration curve of standard vitamin C (n=3)

Table 2: The antioxidant activity

\begin{tabular}{|c|c|c|c|c|c|}
\hline Sample & Concentration $(\mu \mathrm{g} / \mathrm{ml})$ & Absorbance & $\%$ inhibition & Linear regression equation & $\mathrm{IC}_{50}(\mu \mathrm{g} / \mathrm{ml})$ \\
\hline \multirow[t]{5}{*}{ Vitamin C standard } & 2 & $0.432 \pm 0.003$ & $32.448 \pm 0.477$ & $\begin{array}{l}y=7.7318 x+17.755 \\
R^{2}=0.998\end{array}$ & 4.170 \\
\hline & 4 & $0.325 \pm 0.011$ & $49.167 \pm 1.685$ & & \\
\hline & 6 & $0.221 \pm 0.005$ & $65.521 \pm 0.786$ & & \\
\hline & 8 & $0.138 \pm 0.003$ & $78.490 \pm 0.502$ & & \\
\hline & 10 & $0.031 \pm 0.005$ & $95.104 \pm 0.705$ & & \\
\hline \multirow[t]{5}{*}{ Water apple fruit } & 4 & $0.571 \pm 0.002$ & $45.587 \pm 0.220$ & $\begin{array}{l}y=6.0857 x+20.444 \\
R^{2}=0.995\end{array}$ & 4.857 \\
\hline & 5 & $0.523 \pm 0.002$ & $50.159 \pm 0.198$ & & \\
\hline & 6 & $0.461 \pm 0.002$ & $56.127 \pm 0.198$ & & \\
\hline & 7 & $0.383 \pm 0.003$ & $63.556 \pm 0.240$ & & \\
\hline & 8 & $0.318 \pm 0.004$ & $69.714 \pm 0.343$ & & \\
\hline \multirow[t]{4}{*}{ Fragrant mango fruit } & 2 & $0.766 \pm 0.014$ & $16.571 \pm 1.746$ & $\begin{array}{l}y=9.2476 x+9.8794 \\
R^{2}=0.990\end{array}$ & 4.379 \\
\hline & 3 & $0.645 \pm 0.001$ & $27.016 \pm 1.361$ & & \\
\hline & 4 & $0.537 \pm 0.001$ & $38.540 \pm 0.110$ & & \\
\hline & 6 & $0.366 \pm 0.004$ & $54.762 \pm 0.095$ & & \\
\hline
\end{tabular}

Values are mean \pm SD $(n=3)$, SD: Standard deviation 
storage duration and conditions, processing, and physical damage [17] also affect the vitamin $\mathrm{C}$ content.

The antioxidant activity with the DPPH method was characterized by the color alteration, from purple to yellow after incubation for 20 minutes. It is because of the free radical DPPH was reduced to DPPH [18]. Table 2 showed that $\mathrm{IC}_{50}$ value for water apple and fragrant mango was similar as standard vitamin C. Both fruits were classified as a very strong antioxidant because the $\mathrm{IC}_{50}$ value is less than $50 \mu \mathrm{g} / \mathrm{ml}$ [18] due to high vitamin $C$ content (Table 1). The reactive free radical (DPPH) was reduced by vitamin $\mathrm{C}$ (ascorbic acid), and the ascorbyl radical formed in its place is less reactive [19]. Then, the ascorbyl radical loss of a second electron to form the dehydroascorbic acid, which its stability (only a few minutes) depends on factors such as $\mathrm{pH}$ and temperature [20]. The vitamin $\mathrm{C}$ content and the $\mathrm{IC}_{50}$ value for both fruits were statistically significant, due to harvest time which also influenced by climate.

\section{CONCLUSION}

The vitamin C content and antioxidant activity of water apple fruit were higher than fragrant mango fruit.

\section{ACKNOWLEDGMENT}

The authors thank Rubiyani Sumantri and Kiki Rizky Fitriyani for technical assistance.

\section{REFERENCES}

1. Alothman M, Bhat R, Karim AA. UV radiation-induced changes of antioxidant capacity of fresh-cut tropical fruits. Innov Food Sci Emerg Technol 2009;10:512-6.

2. Scalzo J, Politi A, Pellegrini N, Mezzetti B, Battino M. Plant genotype affects total antioxidant capacity and phenolic contents in fruit. Nutrition 2005;21(2):207-13.

3. Saura-Calixto F, Goni I. Antioxidant capacity of the Spanish Mediterranean diet. Food Chem 2006;94:442-7.

4. Bielski BH, Richter HW, Chan PC. Some properties of the ascorbate free radical. Ann N Y Acad Sci 1975;258:231-7.

5. USP, editor. US Pharmacopeia 32. United Stated, Rockville, MD: The United States Pharmacopeial Convention; 2008.
6. Tahirović A, Copra-Janićijević A, Bašić N, Klepo L, Subašić M. Determination of vitamin $\mathrm{C}$ in flowers of some Bosnian Crataegus L. Species. Works Fac Forestry Univ Sarajevo 2012;2:1-12.

7. Saptarini NM, Herawati IE. Comparative antioxidant activity on the Ficus benjamina and Annona reticulata leaves. Int J Public Health Sci 2015;4(1):21-6.

8. Dawson RM, Elliott DC, Elliott WH, Jones KM. Data for Biochemical Research. $3^{\text {rd }}$ ed. Oxford, New York: Oxford University Press; 1986.

9. Silva CR, Simoni JA, Collins CH, Volpe PL. Ascorbic acid as a standard for iodometric titrations. An analytical experiment for general chemistry. J Chem Educ 1999;76(10):1421-6.

10. ICH, editor. Validation of analytical procedures: Text and methodology Q2(R1). In: International Conference on Harmonisation of Technical Requirements for Registration of Pharmaceuticals for Human Use. London: European Medicines Agency; 2005.

11. BPTPT. Biologi Bunga Dan Teknik Penyerbukan Pada Jambu Biji; 2016. Available from: http://www.balitbu.litbang.pertanian.go.id/ind. [Last cited on 2016 Sep 20].

12. Trubus. Pilihan Baru Berkebun Mangga. Trubus; 2016. Available from: http://www.trubus-online.co.id. [Last cited on 2016 Sep 20].

13. Klein BP, Perry AK. Ascorbic acid and vitamin A activity in selected vegetables from different geographical areas of the United States. J Food Sci 1982;47:941-5.

14. Harris RS. Effects of agricultural practices on the composition of foods. In: Harris RS, Karmas E, editors. Nutritional Evaluation of Food Processing. $2^{\text {nd }}$ ed. Westport, CT: AVI; 1975. p. 33-57.

15. Weston LA, Barth MM. Preharvest factors affecting postharvest quality of vegetables. Hortic Sci 1997;32:812-6.

16. Kader AA, editor. Influence of Preharvest and Postharvest Environment on Nutritional Composition of Fruits and Vegetables. The $1^{\text {st }}$ International Symposium on Horticulture and Human Health. Englewood Cliffs, NJ: Prentice-Hall; 1988.

17. Lee SK, Kader AA. Preharvest and postharvest factors influencing vitamin $\mathrm{C}$ content of horticultural crops. Postharvest Bio Technol 2000;20:207-20.

18. Molyneux P. The use of the stable free radical diphenylpicryl-hydrazyl (DPPH) for estimating antioxidant activity. Songklanakarin J Sci Technol 2004;26(2):211-9.

19. Buettner GR, Moseley PL. EPR spin trapping of free radicals produced by bleomycin and ascorbate. Free Radic Res Commun 1993;19 Suppl 1:S89-93.

20. Washko PW, Wang Y, Levine M. Ascorbic acid recycling in human neutrophils. J Biol Chem 1993;268(21):15531-5. 